\section{Which empowerment, which Health Promotion? Conceptual convergences and divergences in preventive health practices}

\author{
Que empowerment, qual Promoção da Saúde? \\ Convergências e divergências conceituais em \\ práticas preventivas em saúde
}

\author{
${ }_{1}^{1}$ Laboratório de Atividade \\ Física e Promoção da Saúde, \\ Universidade do Estado do \\ Rio de Janeiro, Rio de Janeiro, \\ Brasil. \\ 2 Escola Nacional de Saúde \\ Pública Sergio Arouca, \\ Fundação Oswaldo Cruz, \\ Rio de Janeiro, Brasil. \\ Correspondence \\ M. S. Ferreira \\ Laboratório de Atividade \\ Física e Promoção da Saúde, \\ Universidade do Estado do \\ Rio de Janeiro. \\ Rua São Francisco Xavie \\ 524, Bloco F, sala 8133, \\ Rio de Janeiro, $R J$ \\ 20550-900, Brasil. \\ msantosferreira@uol.com.br
}

\section{Abstract}

Based on the multiple meanings, "empowerment" can be identified with either conservative or critical Health Promotion approaches. From a conservative approach, the concept is viewed as an essentially individual phenomenon, centered on the provision of information and the external transfer of power in the name of the collective good. From this approach, the relationship between "psychological" and "community" empowerment is not considered. From a critical approach, the concept is viewed as a relational phenomenon that manifests itself in the dialectic conflict of interests between individuals, groups, and social classes. From this approach, "psychological" and "community" empowerment are seen as micro and macro levels of analysis, and social transformations are the result of simultaneous changes at these levels. The use of the notion of empowerment without critical reflection or political analysis of power relations in society disseminates vague, romantic, and homogeneous views of "community". Therefore, to assume the relational nature of empowerment means to accept its interdependence with the notion of participation, without which there can be no social transformation. Thus, one should be vigilant about multiple meanings that empowerment can given in Health Promotion discourse.

Health Promotion; Social Participation; Public Health Practice
Marcos Santos Ferreira 1

Luis David Castiel 2

\section{Introduction}

Health Promotion can serve not only proposals committed to the status quo but also projects for social change 1 , because in a sense its key ideas are susceptible to this ambiguity. It is thus relevant to analyze how "empowerment", considered the central thrust of Health Promotion 2,3,4,5,6,7,8,9, can serve this role. One reason doubtless lies in the multiple meanings assigned to the category of empowerment $2,3,9$, to the point of being viewed as something to be surmounted in favor of transformation 2 or as a way of masking contact with the current form of political economy and consumer capitalism 10,11.

Although the meanings assigned to the English-language verb "empower" in Portuguese are "to give power, authorize, license, entitle, enable, allow" 12 (p. 250), the term lacks a proper equivalent in Portuguese itself. Nevertheless, various scholars from the health field have translated "empowerment" into Portuguese by using the Anglicism empoderamento 3,13 . Considering that this Anglicism not only sounds odd in Portuguese but can also disguise the term's various nuances, we prefer to maintain the original English word. Indeed, this multiplicity of approaches to empowerment is fertile ground for drawing on it as a form of social control 14 and hiding conservative practices 15 . We thus propose to examine the term empowerment, its use in the Health Promotion field, and the meanings usually ascribed 
to it. We will identify and discuss different approaches to the empowerment category in order to support our position, which we explicitly assume as favoring a critical approach that can contribute to changing the Brazilian context of social inequality.

\section{The emergence of the notion of empowerment and Health Promotion}

Health Promotion took shape beginning in the 1970s in reaction to the high costs of a hospitalcentered, curative-based health system. After all, if disease can be prevented, why let it happen in the first place? Despite the clear shift in focus from cure to disease prevention, beginning in the 1980s the underlying set of ideas in Health Promotion began to encompass other key ideas: defense of the community's participation in defining and seeking solutions to its health problems and a critique of the emphasis on individual behavior changes (read "lifestyles") and the doctor figure as the only professional responsible for health.

In our view, empowerment, as the antithesis of the notion of powerlessness, fits perfectly with this new perspective of Health Promotion that was taking shape since the 1980s and that was intended to supplant the disease-prevention and behaviorist emphasis marking the 1970s. Some authors, like Rappaport 16, praise empowerment as a means to surmount the preventionist focus, with the argument that there is not only a single response to social problems. According to this reasoning, the solution to social problems involves multiple and complex possibilities that would become more feasible if social policies were based on the notion of empowerment. Meanwhile, empowerment should not be viewed as a monolithic construct, much less as a cure-all for the challenges raised within and by the health field 17. The notion of empowerment should be based on pluralistic thinking that encourages diversity by means of participation by different social groups in the search for solutions to their health problems, as opposed to the centralizing approach of agencies and institutions that control resources, value convergent thinking, and attempt to standardize the ways people live their lives 16 .

In the 1980s, especially beginning with the Ottawa Conference in 1986, empowerment was mentioned as one of the central ideas in Health Promotion 4,17,18, more precisely as the thrust of "strengthening community action" highlighted in the Ottawa Charter as one of Health Promotion's areas of action. The centrality of empowerment to Health Promotion was further highlighted in other conferences 5,19 and at the 51 st World Health Assembly of the World Health Organization (WHO) 20. This centrality is due to the fact that empowerment incorporates the very raison d'être of Health Promotion 14, expressed in the strong similarity between the two concepts. Empowerment is generally defined as "a process through which people gain greater control over decisions and actions affecting their health" 21 (p. 6), and Health Promotion as "the process of enabling people to increase control over, and to improve, their health" 6 (p. 1). Several questions arise from this concept that are central to an understanding of empowerment.

\section{Empowerment and power}

The issue here is not to trace the intricate theoretical trajectories of studies on the theme of power and its derivations, which are beyond the scope of the current article. Rather, the challenge is to reflect on the fact that the verb "to empower" can assume both transitive and intransitive forms 8 . As transitive, it requires the presence of one or more complements for the action to gain meaning. In this case, the subject practices the action (to empower) for someone. The underlying idea is that power is granted, transferred from a person or groups to others. But how does this take place? Based on formulas "provided" by the health authorities, populations are called on to intervene in their own health's management. However, one cannot assume that they detain power as persons possessing autonomy (understood as practical capacity in socioeconomic, cultural, political, emotional, and cognitive terms) to evaluate those formulas, accepting or refusing them without causing themselves harm. One cannot assume that they detain power if they do not participate actively in defining their health problems and formulating proposals for overcoming the situation. Thus, the notion of transferring power serves to legitimize the incapacity for action that persons in those adverse living conditions may experience.

When intransitive, the verb does not accept a complement to gain meaning. In this case, the action (to empower) is practiced by and for the subjects or communities themselves. Here, the underlying idea is that power is conquered by one's self, by the person or groups. This perspective relates to actions that serve for populations to take power for themselves, which is thus not possible unless they adopt a stance of greater protagonism in the action. However, this perspective appears not to prevail in Health Promotion practices, which in our opinion is explained by its 
visceral connection to the state 22 . Having been born under the state's auspices and heavily linked to it, how could Health Promotion spawn actions that would prepare people to challenge it?

However, such distinctions are not always made or are not always clear in Health Promotion texts and practices, a fact that definitely contributes to the lack of conceptual definition in the term "empowerment", as discussed above. This may explain why some people highlight the intransitive nature of the verb in its spelling, identifying self-empowerment as a central element in health education programs developed from the Health Promotion perspective 23. Meanwhile, Health Promotion proponents view empowerment as a phenomenon that occurs when power is transferred from one party to another ${ }^{9}$. But is this possible? Can empowerment be seen as something granted by someone to somebody else?

The answer to this question requires a closer look at the meanings ascribed to the notion of power. In this case, it is particularly enlightening to consult Foucault's reading of power, the concept underlying the notion of empowerment: power involves a relationship of forces and is thus everywhere, not only in the state and its institutions 24 . Thus, power is not an object, a thing, but a relationship 25. In this sense, there is no room for the idea that power can be granted by someone to somebody else as "something" that comes from outside. Power takes shape to the extent that any and all social relationships are established. Power is not an attribute of individuals and communities, but an expression of the relationship between two entities 26 . Thus, the capacity for empowerment exists in all persons in the context of the countless possibilities for relationships they establish with each other 26 .

There is no power whose essence can be defined by universal characteristics 24 . There is not a single, unitary, global thing called power, but diverse, heterogeneous forms in constant transformation 25 . In short, assuming the relational nature of power as the basic premise for discussions on empowerment implies rejecting the idea of its external, altruistic transfer, as if it were an entity, a thing. Thus, to accept empowerment merely as transfer of power would be a way of supporting its most improbable version, most amenable to non-confrontational uses. To allow this concept of empowerment means to view the "empowered" as passive elements, thereby helping obfuscate the idea that wherever there is power, there is also resistance 24 . In fact, empowerment is frequently used to disguise the social control function of health professionals that address populations with pre-formulated con- cepts as guidelines for elaborating and evaluating their actions ${ }^{11}$. In short, no one "empowers" anyone 15,26. Empowerment is not something that can be given; it must be won 27 .

Nevertheless, we do not deny the (theoretical) possibility of power being "turned over" in real life, i.e., being transferred altruistically. Still, we do not view it as a hypothesis to base the discussions on empowerment from a critical perspective. This would mean taking the exception as the rule, a part as the whole. In our view, power is not transferred without conflict. Many of the decisions made by those who aim to maintain power are apparently reached by consensus, but in fact they are minor concessions made with the objective of maintaining major privileges. However, any analysis of the possibility of transferring power should be based on the multiple and often contradictory relations between the parties involved. According to this reasoning, it is possible to identify the dialectic nature of power and, by extension, of empowerment, sometimes viewed as an action involving transfer of power to others, and other times as self-conquering of power.

When one side needs to lose power for the other to gain it, it is called a "win/lose" or "zerosum" relationship 26 . This type of power is finite, since it is impossible for someone to improve their social status (where the latter, by definition, is a comparative measure) without others worsening their condition; it is likewise impossible for social minorities to obtain gains against discriminatory practices (racial and gender-based, for example) without other groups losing part of their power over such practices; or that economic exploitation be overcome without the exploiters losing control over their capital 26 .

Meanwhile, a relationship in which everyone wins, or a "win/win" or "nonzero-sum relationship" as it is known in English, is a manifestation of power which can (and should) expand without limits, since it refers to situations characterized by the ethics of mutual respect, reciprocity, humility, and interdependence between the parties 26 . However, we contend that this type of power manifests itself most frequently in situations where the parties involved have common interests. In a broader context, such interests will differ in turn from those of other social groups. Besides, the reality of political and economic power distribution does not produce scenarios in which everyone wins 15 . Therefore, conceiving of empowerment as a relationship means that win/lose and win/win situations occur conflictingly, simultaneously, and dialectically.

The myriad of approaches to empowerment further includes the notions of "power over" and "power with" 8 , which in our view express 
similar relations to "zero-sum" or "win/lose" and "non-zero-sum” or "win/win”, respectively. Let us examine how these notions can manifest themselves in a very common situation in countries like Brazil.

When health agents approach a given poor community (i.e., poor in terms of economic power, rights, and social justice) with the objective of eradicating the Aedes aegypti mosquito and consequently the dengue epidemic, whether one likes it or not, power relations are established between the parties involved. If the agents limit themselves to advocating decontextualized preventive measures (generally based on individual behavior changes), previously conceived and designed according to their own worldview, and assessing their effectiveness on the basis of faithful completion of the measures by the community residents, what prevails is a relationship of "power over". Such actions generally translate as the distribution of information leaflets and posters, designed behind closed doors and without the community's participation.

On the other hand, if the health agents attempt to learn about the residents' reality and the problems defined by them and if they seek to encourage a critical and more in-depth reflection among the residents, not only on the biological determinants, rather especially on the environmental, social, economic, cultural, and political determinants of a given disease, what prevails is a relationship of "power with".

However, more egalitarian arrangements for the interaction between health professionals and groups of individuals, based on the "power with" notion may represent a stride forward, but can ignore structural differences (of social class and educational and professional background, for example) between the parties involved 9. Taking a more rigorous stance, some authors 10 contend that even when empowerment is based on the notion of "power with", it cannot be seen as a means for strengthening collective action against the power structures, but as a consensus-building method that requires negotiation and social "concertation". How could health agents (who conduct the mediation between the aspirations of the most disempowered population strata and the interests of groups occupying power positions in society) play their role without serving as a reference for reconstructing the social identities of the excluded groups? Could this not be seen as a new form of tutorship over the majority of the population? 10 .

A similar question has arisen concerning the roleofnongovernmentalorganizations(NGOs) in relation to local grassroots social movements 28 . How can the work by NGO representatives fo- cus on the empowerment of the most socially excluded groups without stimulating the power hierarchies? Some political and pedagogical orientations are suggested that can be relevant to social mediation work: recovering the dignity of socially excluded subjects involves the deconstruction of discriminations introjected by them (without which there can be no struggle for rights), and positively reclaiming their cultural, symbolic, and aesthetic roots (without renouncing transformational self-critical evaluations), so as to bolster (new) forms of grassroots collective action with a view towards confronting and solving social problems 28 .

However, the actual implementation of such actions goes far beyond simply supplying information to the excluded. In addition to specific skills for dealing with problems of social exclusion, the struggle to overcome them should be based on solidarity between individuals and different social groups. The question is, how can such feelings of solidarity emerge in such adverse contexts, marked by unequal participation by subjects and social groups in the process of producing a nation's goods and wealth? How can this vicious circle be broken?

However, one cannot deny that information on the etiology of certain diseases can help expand that community's decision-making power in relation to its own health - granted, of course, that people can understand and assimilate the information, whose difficulty is proportional to the social chasm between the stakeholders (health agents and community members). The knowledge that hot weather and still clean water are ideal conditions for the dengue mosquito to reproduce is no guarantee in itself, but it may lead local residents to cover recipients and other sites where clear water is accumulated or stored, which would help mitigate the epidemic. However, this purported increase in power is limited to the individual level. On the part of the state, represented by the health agents, no power was transferred to the local residents. For example, they were not granted the right to decide on the amount of public funds to be invested to fight that disease and to solve other related health problems.

Meanwhile, in addition to providing information, critical reflection on the social, economic, and political determinants of health problems can foster a greater grasp and understanding by residents of the risks of the specific disease and their health in general, expanding their possibilities for interpreting their living conditions and perhaps leading them to fight for more radical social changes, like income and land redistribution and universal access to education and health 
services, among others. Could such actions be viewed as the expression of greater power for that group of residents? Yes, in a sense. Yet it is a kind of power for the struggle for power, that is, power that only materializes through social interaction and to the extent that the conflicting interests play out, and not power that has been granted, or transferred by someone else as "something" coming from outside.

While contending that most programs with a behavioral approach (based on the idea of epidemiological risk) tend to adopt the notion of "power over" to deal with community health issues, the possibility of empowerment by means of these programs is admitted 8. For example, when a health officer in a cardiac rehabilitation program reflects on what can be done to support his patients in overcoming their forms of oppression (on grounds of class, gender, and culture), understanding the latter as conditioning factors in their heart disease and seeking results beyond morpho-physiological adaptations, his practice is based on empowerment 8 .

However, we raise several caveats in this case. By themselves, programs with this approach cannot "empower", because they do not confer power to anyone 15 . Besides, empowerment by means of programs with a behavioral focus and based on the idea of epidemiological risk are generally restricted to the individual level. Thus, in our view, it is highly unlikely that members of programs with this focus will succeed in overcoming the limits imposed by the quantitative approach to phenomena. Even if programs are not limited to the specific disease and its epidemiological risk factors, and even if they include critical reflection by users concerning the forms of oppression they experience, at best they help persons expand their capacity to struggle for power.

This situation becomes even worse when the range of possibilities for collective construction of alternatives is limited. The presentation of individual solutions to essentially collective problems often serves to eclipse the correlation of forces between different social classes and to shift attention away from essential issues for reversing Brazil's historical social inequality. The defense of changes in lifestyles that only partially explain the emergence of diseases 29 is one of the most common forms of victim blaming. Likewise, in our view, to equate empowerment with the provision of information or to limit it to the individual level makes it useless for social change.

During the 1990s, the health field witnessed the emergence of the concept of vulnerability, according to which the probability of persons being exposed to illness results from a set of aspects, not only individual, but also collective and con- textual 30,31, thereby representing an effort at surmounting the restrictive focus of epidemiological risk. In fact, the vulnerability concept subsumes those of "risk group" and "risk behavior", bringing up new perspectives for health. For example, rather than the "probability" of outcomes there is the "potential" for illness/non-illness, since there are relations that are not always demonstrable in mathematical terms. Rather than acritical universality, there is the consideration of different social contexts as determining susceptibilities. Rather than independence between groups whose intersection the probabilistic analyses aim to estimate, there is an emphasis on the relational dimension of any and all social practice 30 . In this sense, the concept of vulnerability indicates the need for reconstruction of social relations 30 (something which can thus not be conceived without considering the complex power relations).

\section{Psychological and community empowerment}

Empowerment is a phenomenon that can occur at different levels ${ }^{9}$, and to deal with this complexity, it is appropriate to analyze the psychological, organizational, and community levels 32,33 . At the psychological level, empowerment encompasses perceptions of social control, a proactive stance towards life, and a critical understanding of the socio-political environment. At the organizational level, it includes processes and structures that enhance personal skills and allow the members of a community to support each other and produce changes in it. At the community level, it refers to joint organized work aimed at improving collective living conditions 33 .

The distinction between psychological and community empowerment was already implicit in some articles on community psychology 16,27,34, but the formal distinction was made between the terms (although not defined as opposing) in the early 1990s 35 . Since then, various authors 14,32 have further refined this distinction, which has been adopted by others 2 to reflect on empowerment and its role in the Health Promotion context. Although treated differently, the two levels (psychological and community) are interdependent, and the analysis of this interaction is crucial for understanding empowerment. However, on this point there are questions of nomenclature that need to be clarified before proceeding with the discussion.

The term "individual empowerment" has been adopted 14,32 as a synonym for psychological empowerment. In this sense, it would be logical to admit that the use of this synonym can limit the interpretation of psychological empowerment to a construct that only considers what 
occurs in the individual mind 33 . The argument is relevant, especially today, when most of the literature on empowerment focuses on the individual ${ }^{32}$, whence emerges a new type of conservative ideology of individual responsibility that blames victims even more subtly 16 .

This leads us to highlight that some authors 14,17,32 use the term "community empowerment" rather than simply "empowerment" as a way of differentiating it from an exclusively psychological (or individual) approach that ignores the social context. The notion of community empowerment includes: (a) an increased level of psychological empowerment among the community members; (b) political action by these members; and (c) redistribution of resources or decisionmaking in favor of this community. Meanwhile, psychological empowerment (defined as a feeling of greater control over one's own life that individuals experience when they belong to groups) can occur without participation in collective political action 14 .

Importantly, the term "psychological" is used to refer to the level of individual analysis of empowerment with the aim of expressing a broader interpretation of the construct, beyond just intrapersonal characteristics 33 . Thus, psychological empowerment, which combines the intrapersonal, interactional, and behavior dimensions 33 , is viewed as a level of community empowerment 14,32 , to which it is thus strongly linked. It would thus not be appropriate to treat them as opposing concepts, although they can be distinguished from each other. In our view, the distinction between psychological and community empowerment reflects much more of a didactic function than the intention to make them mutually exclusive, not least because if power is relational, it would make no sense to consider psychological empowerment as merely an individual phenomenon. In short, one can assume that the notion of (community) empowerment encompasses changes at the individual and collective levels and implies a link between these levels of analysis 14,17,32.

From this perspective, community empowerment has been defended as one of the strategies for health reform 2,17, which obviously requires clarity as to the underlying concept of "community". The indiscriminate use of the notion of community empowerment without critical reflection and political analysis of the power relations in society (and thus without reference to social theories) serves to disseminate fuzzy 22,36 , illusory, romantic 15 , idealized 36 , and homogenized visions of "community". In our view, the combination of these views leads to "blaming victimized communities" 15 , a collec- tive and even more perverse version of victim blaming.

\section{The dissemination of the (ambiguous) concept of empowerment}

Especially since the 1990s, the emphasis on empowerment has expanded to a broad variety of organizations, areas of knowledge, and professional fields. For example, while empowerment is viewed by the World Bank as one of the means for overcoming poverty 37 , it is also taken as the basis for discussion on the relationship between extension experts and farmers 38 , as a means for networking social movements 28 , as the central idea for programs on nutritional education 39 , as an innovative practice for work management and personal development 40 , and even as a strategy for increasing life expectancy 41 .

Could empowerment really mean the same for all these organizations, areas of knowledge, and professions that draw on it as a reference for their actions? Not really. In the business sector, for example, empowerment has been used as a means to increase company productivity $17,42,43,44$. Growing competitiveness has been identified as one of the forces that require new approaches for the survival of companies in an increasingly globalized environment. In this sense, beginning in the 1990s, workers' empowerment emerged as one of the most promising innovations 44,45 , an approach that has been discussed in domestic 42,46 and foreign articles 43,44,45 and books published in Brazil 47,48.

Some aspects of the approach to empowerment in the business sector deserve examination. For example, the "bottom-up" sense characterizing empowerment actions from a transforming perspective 14 and which is thus defended for social policies 16 is inverted when empowerment is taken as a strategy in the business environment: "The process starts with the open and enthusiastic expression of the need and desire for empowerment to take place. This thrust must come from the very top, the business leader, and needs to be echoed throughout the management team of the organization" 44 (p. 78, our emphasis).

In addition, the business sector treats empowerment as a transfer of power from upper to lower echelons $42,43,44,46,47,48$. It is thus a limited, temporary transfer of power, tied to the interests of those who detain greatest power in the company. This empowerment was not won by workers, but granted as a survival strategy in an increasingly competitive market. It could thus not exceed certain limits. In fact, there are few 
examples of more radical empowerment in the business sector 48

We do not wish to deny the possibility that this notion of empowerment in companies can contribute to workers obtaining improvements in the workplace. Yet this does not mean accepting this empowerment approach as a way of achieving any kind of more radical change. It is thus a conservative version, to the extent that it subliminally transfers responsibilities to the worker.

On the other hand, from a critical perspective, some authors view the possibility of empowerment serving as one of the means for transforming the living conditions of the socially excluded $2,3,9,18,28$. In school, for example, empowerment would be expressed as the ability of students, teachers, parents, and staff to achieve greater understanding and control over the social, economic, and political factors that directly affect them 18. They would thus be more able to analyze and interpret their living conditions. The argument is that in this process of jointly reflecting on their health problems, people learn from each other and generate knowledge to which they would not have access individually 39 . Although to a lesser degree, since it is far from hegemonic, the critical approach to empowerment has social transformation as one of its horizons.

\section{Final remarks}

As we have seen, empowerment, one of the key ideas of Health Promotion, is a complex concept that is widely used by various areas of knowledge, although with different meanings. In conservative Health Promotion approaches, empowerment is treated essentially as the external and altruistic transfer of power in the name of the common good. Such approaches thus emphasize strategies that seek a consensus among distinct groups and social classes. In this sense, the transfer of power, when it occurs, is calculated so as to not exceed the limits that challenge the supremacy of subjects of action, taken as unidirectional. This is generally the meaning ascribed to empowerment, especially in the business sector. Conservative approaches tend to overlook the relations between psychological and community empowerment, prioritizing the former over the latter.
In critical Health Promotion approaches, empowerment is understood as an essentially relational phenomenon, i.e., that only manifests itself in the dialectic interplay of conflictive interests between subjects, groups, and social classes. In this sense, it is not appropriate to conceive of psychological and community empowerment as opposing, but basically as micro and macro analytical levels of a broader concept (empowerment), to which one could also include the organizational level (considered intermediate). Social transformations, the greater objective of critical Health Promotion approaches, are viewed as the result of simultaneous changes at the individual and collective levels. Psychological empowerment is thus seen as a necessary but not sufficient condition.

Society is not the sum of its individuals, or much less a homogenous whole. Therefore, empowerment should be viewed not as something that is granted, but rather won in the power game that plays out between the parties. The relational nature of power means that the very struggles against its exercise cannot be waged from outside, from somewhere else, since nothing is devoid of power 25 . To assume the relational nature of empowerment thus means to accept its interdependence with the notion of participation without which there is no social transformation.

When the complexity and multi-dimensional nature of empowerment are not taken seriously, they lead to ambiguity that can be exploited (intentionally or unintentionally) by those who lack commitment to social change. There are those who rightfully denounce conservative approaches to empowerment as a form of social control and maintenance of the status quo. However, we should recall that the discussion on other approaches to empowerment would help move Health Promotion in a more critical direction, more conducive to change. In our view, to deny other approaches (like the concept of vulnerability) and other possibilities for empowerment would mean throwing the baby out with the bathwater 49 . It is thus important to explore both the potentials and limits of these concepts for building more democratic and emancipating social practices. It is important to adopt a vigilant stance towards the multiple forms that empowerment can take in the different professional and scientific fields, including in the Health Promotion ideals. 


\section{Resumo}

Os múltiplos sentidos conferidos ao empowerment podem aproximá-lo de abordagens tanto conservadoras quanto críticas de Promoção da Saúde. Em roupagem conservadora, empowerment é tomado como fenômeno essencialmente individual, baseado na provisão de informação, e como transferência externa de poder em nome do bem comum. Nessa perspectiva, não são consideradas as relações entre "empowerment psicológico" e "comunitário". Em abordagem crítica, empowerment é visto como fenômeno relacional, que só se manifesta no jogo dialético de conflitos de interesses entre sujeitos, grupos e classes sociais. Nessa perspectiva, "empowerment psicológico"e "comunitário" são tomados como níveis micro e macro de análise, e as transformações sociais como resultado de mudanças simultâneas nestes níveis. O uso da noção de empowerment sem reflexões críticas e análises políticas das relações de poder na sociedade dissemina visões vagas, românticas e homogêneas de comunidade. Portanto, assumir o caráter relacional do empowerment significa aceitar sua interdependência com a noção de participação, sem a qual não há transformação social. Sendo assim, deve-se adotar postura vigilante acerca das múltiplas formas que o empowerment pode assumir nos discursos da Promoção da Saúde.

Promoção da Saúde; Participação Social; Prática de Saúde Pública

\section{References}

1. Carvalho SR. As contradições da Promoção da Saúde em relação à produção de sujeitos e a mudança social. Ciênc Saúde Coletiva 2004; 9:669-78.

2. Carvalho SR. Os múltiplos sentidos da categoria "empowerment" no projeto de Promoção à Saúde. Cad Saúde Pública 2004; 20:1088-95.

3. Gohn MG. Empoderamento e participação da comunidade em políticas sociais. Saúde Soc 2004; 13:20-31.

4. World Health Organization. Health promotion evaluation: recommendations to policy-makers Report of the WHO European Working Group on Health Promotion Evaluation. Copenhagen: World Health Organization; 1998.

5. World Health Organization. Sundsvall statement on supportive environments for health. Sundsvall: World Health Organization; 1991. (Document WHO/HPR/HEP/95.3).

6. World Health Organization. Ottawa charter for health promotion. Ottawa: World Health Organization; 1986. (Document WHO/HPR/HEP/95.1).

7. MacDonald TH. Rethinking health promotion: a global approach. London: Routledge; 1998.

\section{Contributors}

M. S. Ferreira was responsible for the theoretical conception and writing and revising the article. L. D. Castiel participated in the theoretical discussion and revision of the article.
8. Labonte R. Health promotion and empowerment: reflections on professional practice. Health Educ Q 1994; 21:253-68.

9. Robertson A, Minkler M. New health promotion movement: a critical examination. Health Educ Q 1994; 21:295-312.

10. Stotz EN, Araújo JWG. Promoção da Saúde e cultura política: a reconstrução do consenso. Saúde Soc 2004; 13:5-19.

11. Grace V. The marketing of empowerment and the construction of the health consumer: a critique of health promotion. Int J Health Serv 1991; 21: 329-43.

12. Houaiss A. Dicionário inglês-português. Rio de Janeiro: Editora Record; 1982.

13. Lefèvre F, Lefèvre AMC. Saúde, empoderamento e triangulação. Saúde Soc 2004; 13:32-8.

14. Rissel C. Empowerment: the holy grail of health promotion? Health Promot Int 1994; 9:39-47.

15. Labonte R. Community empowerment: the need for political analysis. Can J Public Health 1989; 80:87-91. 
16. Rappaport J. In praise of paradox: a social policy of empowerment over prevention. Am J Community Psychol 1981; 9:1-25.

17. Wallerstein N, Bernstein E. Introduction to community empowerment, participatory education, and health. Health Educ Q 1994; 21:141-8.

18. Simpson K, Freeman R. Critical health promotion and education: a new research challenge. Health Educ Res 2004; 19:340-8.

19. World Health Organization. The Bangkok charter for health promotion in a globalized world. Bangkok: World Health Organization; 2005.

20. World Health Organization. Health promotion. Geneva: World Health Organization; 1998. (Document WHA51.12).

21. Nutbeam D. Health promotion glossary. Geneva: World Health Organization; 1998.

22. Stevenson HM, Burke M. Bureaucratic logic in new social movement clothing: the limits of health promotion research. Can J Public Health 1992; 83 Suppl 1:47-53.

23. Tones K. Health education and the ideology of health promotion: a review of alternative approaches. Health Educ Res 1986; 1:3-12.

24. Foucault M. Microfísica do poder. Rio de Janeiro: Editora Graal; 1979.

25. Machado R. Introdução: por uma genealogia do poder. In: Foucault M, organizador. Microfísica do poder. Rio de Janeiro: Editora Graal; 1979. p. viixxiii.

26. Bernstein E, Wallerstein N, Braithwaite R, Gutierrez L, Labonte R, Zimmerman M. Empowerment forum: a dialogue between guest editorial board members. Health Educ Q 1994; 21:281-94.

27. Rappaport J. The power of empowerment language. Soc Policy 1985; 16:15-21.

28. Scherer-Warren I. Das mobilizações às redes de movimentos sociais. Revista Sociedade e Estado 2006; 21:109-30.

29. Syme L, Berkman LF. Social class, susceptibility and sickness. Am J Epidemiol 1976; 104:1-8.

30. Ayres JRCM, França Junior I, Calazans GJ, Saletti Filho HC. O conceito de vulnerabilidade e as práticas de saúde: novas perspectivas e desafios. In: Czeresnia D, Freitas CM, organizadores. Promoção da saúde: conceitos, reflexões, tendências. Rio de Janeiro: Editora Fiocruz; 2003. p. 117-39.

31. Meyer DEE, Mello DF, Valadão MM, Ayres JRCM. "Você aprende. A gente ensina?" Interrogando relações entre educação e saúde desde a perspectiva da vulnerabilidade. Cad Saúde Pública 2006; 22:1335-42.

32. Israel BA, Checkoway B, Schulz A, Zimmerman M. Health Education and community empowerment: conceptualizing and measuring perceptions of individual, organizational, and community control. Health Educ Q 1994; 21:149-70.
33. Zimmerman MA. Psychological empowerment: issues and illustrations. Am J Community Psychol 1995; 23:581-99.

34. Rappaport J. Terms of empowerment/exemplars of prevention: toward a theory for community psychology. Am J Community Psychol 1987; 15:12148.

35. Wallerstein N. Powerlessness, empowerment, and health: implications for health promotion programs. Am J Health Promot 1992; 6:197-205.

36. Castiel LD. Promoção de saúde e a sensibilidade epistemológica da categoria "comunidade". Rev Saúde Pública 2004; 38:615-22.

37. Narayan D, editor. Empowerment and poverty reduction: a sourcebook. Washington DC: The World Bank; 2002.

38. Machado JD, Hegedüs P, Silveira LB. Estilos de relacionamento entre extensionistas e produtores: desde uma concepção bancária até o "empowerment". Ciênc Rural 2006; 36:641-7.

39. Kent G. Nutrition education as an instrument of empowerment. J Nutr Educ 1988; 20:193-5.

40. Souza E, Teixeira JCA, Neris JS, Rios MC. Padrões de adoção de práticas inovadoras de produção e organização no Brasil. Revista de Práticas Administrativas 2004; 1:85-93.

41. Determinantes sociais da saúde: desafio para ricos e pobres. Informe ENSP 2006; 23 ago. http://www. ensp.fiocruz.br/informe $/$ materia.cfm?matid $=1148$ \&saibamais=1149 (accessed on 23/Aug/2006).

42. Rodrigues CHR, Santos FCA. Empowerment: ciclo de implementação, dimensões e tipologia. Gestão \& Produção 2001; 8:237-49.

43. Margulies JS, Kleiner BH. New designs of work group: applications of empowerment. Empowerment in Organizations 1995; 3:12-8.

44. Gandz J. The employee empowerment era. Business Quarterly 1990; 55:74-9.

45. Randolph WA. Navigating the journey to empowerment. Organ Dyn 1995; 23:19-32.

46. Rodrigues CHR, Santos FCA. Empowerment: estudo de casos em empresas manufatureiras. Gestão \& Produção 2004; 11:263-74.

47. Tracy D. 10 passos para o empowerment: um guia sensato para a gestão de pessoas. Rio de Janeiro: Editora Campus; 1994.

48. Slack N, Chambers S, Harland C, Harrison A, Johnston R. Administração da produção. São Paulo: Editora Atlas; 1997.

49. Davison C, Smith GD. The baby and the bath water: examining socio-cultural and free-market critiques of health promotion. In: Bunton R, Nettleton S, Burrows R, editors. The sociology of health promotion. London: Routledge; 1999. p. 91-9.

Submitted on 17/Aug/2007

Final version resubmitted on 11/Dec/2007

Approved on 10/Jan/2008 